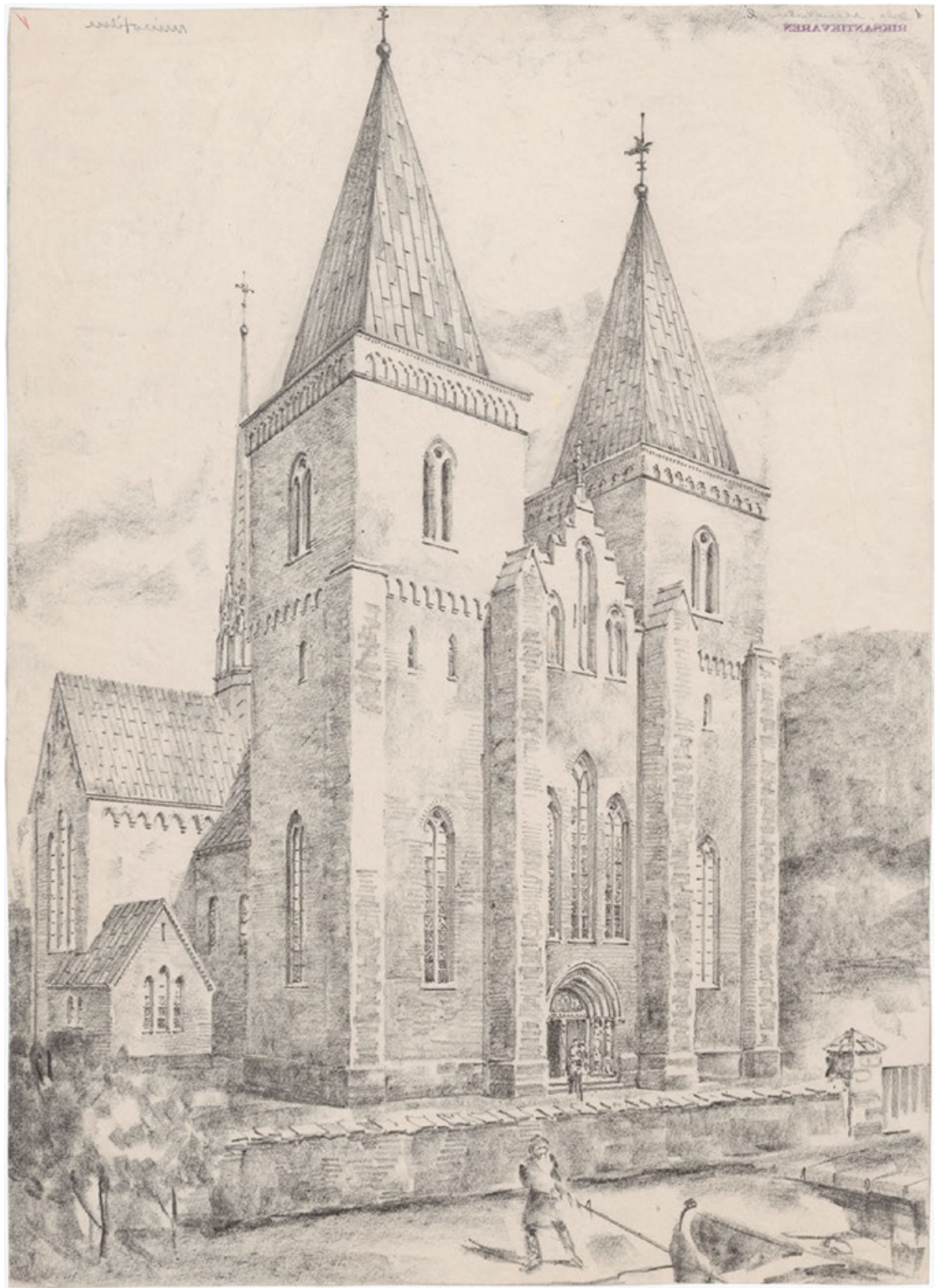

Fig. 9.1: St Mary's Church, Oslo. Reconstruction of the façade by Harald Sundt, 1926. The church, erected in the twelfth century and demolished in 1542, was a royal chapel with its own chapter, independent of the bishop of Oslo.

D Open Access. () 2021 Lena Liepe, published by De Gruyter. (c) BY-NC-ND This work is licensed under the Creative Commons Attribution-NonCommercial-NoDerivatives 4.0 International License.

https://doi.org/10.1515/9783110639438-010 
Lena Liepe

\section{Chapter 9 \\ The Crown of Thorns and the Royal Office in Thirteenth- and Fourteenth-Century Scandinavia}

Inventory lists and diplomas reveal that precious pieces of Christ's crown of thorns were in the possession of several Scandinavian rulers in the thirteenth and fourteenth centuries. In three cases the thorn relics are reported to have been gifts from the French kings Philip III and Philip IV to their Scandinavian counterparts, thus forming a direct link to the Holy Crown that King Louis IX had brought to Paris and placed in the Sainte-Chapelle. This chapter explores how these thorn relics, and also other passion relics such as fragments from the Cross, not only served as tangible presences of Jerusalem in the royal churches where they were kept, but may also have contributed to the ideological construction of the king as a ruler by divine right after the model of Louis IX. It is further suggested that Philip IV's gift to Norwegian king Magnus V Haakonsson of a relic of St Louis (Louis IX) together with the thorn relic may be read as a message about the obligations of a Christian ruler to take on the role of the crusader in the winning back of the kingdom of Jerusalem.

“The treasures here accounted for are in St Mary's Church in Oslo in Your Majesty's realm Norway." These are the opening words of an inventory of the valuables of the said church, compiled in 1523 or 1524 for King Christian II of Denmark (1481-1559). ${ }^{1}$ The list is long: it contains a large cross mounted with gold and gems, a silver base for yet another cross, a gilded image of the French royal saint Louis IX, a gilded image of the Swedish royal saint Erik, two chalices with patens in gold and a smaller chalice made from silver, three censers, two small gilded crosses, four

1 DN, vol. 8, 528. The date of the inventory is deduced from its mention in the text of Hans Mule (d. 1524), the later bishop of Oslo, who is referred to as mesther Hans Mule. Mule was elected bishop by the chapter of Oslo Cathedral in 1521, but was ordained only in the autumn of 1524, when the pope's consent was finally given. Nicolay Nicolaysen assumed that the inventory list was written before 1521 (Nicolay Nicolaysen, Norske fornlevninger. En oplysende fortegnelse over Norges fortidslevninger, ældre end reformationen og henførte til hver sit sted, Foreningen til norske fortidsminnesmerkers bevaring (Kristiania: Carl C. Werner \& Comp’s Bogtrykkeri, 1862-1866), 30 n. 3). In doing so he overlooked Hans Arildson's concluding words about all the treasures being transferred to Akerhus Castle the days before the Swedish troops invaded Oslo, i.e. in late March 1523. Thus, the list must have been compiled sometime between April 1523 and August/September 1524 (cf. DN, vol. 8, 528 n. 1).

Lena Liepe, Professor of Medieval Art History, Linnaeus University, Växjö, Sweden 
silver crowns, large and small clasps in precious metal, three gilded and silverplated bowls, a large gilded monstrance for the main altar, two smaller monstrances, some ten to twelve books with gilded covers studded with pearls and gems, the church's vestments and liturgical textiles, and its collection of letters and documents. Listed are also a number of objects that belong to a particular category of church treasures, namely, reliquaries in precious metal: two gilded angels holding a fragment of the Lord's crown of thorns; a silver-plated board set with relics; a tall, gilded reliquary; and three or four smaller reliquaries, one gilded and the others silver plated. The compiler of the list, Hans Arildson, concludes by informing the king that all the valuables had been transferred from the church to Akershus Castle only days before the Swedish and Lübeck troops arrived in Oslo, i.e. at the end of March 1523.

A French source from the early fourteenth century provides additional information regarding the acquisition of the thorn reliquary supported by angels and the gilded statuette of St Louis. This 1304 account of the jewels belonging to King Philip IV of France (1268-1314) reveals that a gift was sent that year from the French king to the "Roi de Noroi”, in other words, to King Haakon V Magnusson of Norway (1270-1319). The gift consisted of two gilded silver angels with a thorn relic, as well as an image made from silver of St Louis, adorned by a golden crown and holding a finger bone from the saint. Arne Odd Johnson, who was the first to bring this source to light, makes the likely assumption that the thorn reliquary and the silver figure are identical to the items mentioned in the 1523/24 list, and he further suggests that King Haakon bequeathed the reliquaries with their content to St Mary's Church as part of the institutionalization of that church as a royal chapel. ${ }^{2}$

A further, albeit indirect, connection exists between King Haakon and the silverplated board set with relics listed in the 1523/24 inventory. In his will, written sometime between 1312 and 1319, King Haakon donated seventy marks in pure silver to the Church of the Apostles in Bergen, to be used for the manufacturing of a relic board "ad modum tabule reliquiarum, que in ecclesia beate Marie virginis in Osloya," that is, like the one found in St Mary's Church in Oslo. ${ }^{3}$ The second decade of the fourteenth century thus represents a terminus ante quem for the Oslo relic board.

\section{Inhabited Liturgical Space}

A medieval church interior was an inhabited space: it was filled by the presence of the saints in the form of their relics. In the main altar, the altar grave or sepulcrum

2 Arne Odd Johnsen, “Ad Filip IV’s relikviegaver til Håkon V (1303-1304),” Historisk tidsskrift 44 (1965): 153-4.

3 DN, vol. 4, 128. 
contained relics deposited there by the bishop when the church was consecrated. Additional relics, if such existed, could be kept in shrines and in reliquaries small enough to be put on display and carried around in processions at the major church feasts. Today, few traces remain in Scandinavia of the once prolific medieval cult of saints' relics. After the Lutheran reformation, the saints became obsolete, their remains were no longer deemed to communicate heavenly glory, and the shrines and reliquaries that had once held them were for the most part confiscated and lost. ${ }^{4}$ Perhaps because of their physical absence, relics have until fairly recently failed to attract the scholarly attention they deserve, and their importance for medieval spirituality as well as for political legitimation long remained only a minor feature of medieval cultural history. Recently, however, international research on relics started to boom, as made evident by a major exhibition of relics and reliquaries titled Treasures of Heaven, staged in 2010-2011 in collaboration between the Cleveland Museum of Art, the Walters Art Museum in Baltimore and the British Museum, as well as a wealth of publications on relics and relic veneration in medieval Christianity. ${ }^{5}$

The study of relics allows for a wide array of approaches. Topics dealt with include the institutional framework of the cult of relics, the role of relics in the devotional life of the individual, and, not least, relics as forceful political resources within medieval public life. ${ }^{6}$ The present essay explores the role of relics in late

4 For an overview of surviving reliquaries, see Erik Horskjær and Rune Norberg, "Relikvarium," in KLNM with references.

5 Recent scholarship on relics include Martina Bagnoli et al., eds., Treasures of Heaven: Saints, Relics and Devotion in Medieval Europe (London: The British Museum Press, 2011); Philippe Betia, Les reliques de la passion du Christ: Histoire et spiritualité (Paris: L'Harmattan, 2012); Édina Bozóky, La politique des reliques de Constantin à Saint Louis: Protection collective et légitimation du pouvoir (Paris: Beauchesne, 2006); Jean-Luc Deuffic, ed. Reliques et sainteté dans l'espace médiéval, Pecia. Ressources en médiévistique 8-11 (Turnhout: Brepols, 2005); Charles Freeman, Holy Bones, Holy Dust. How Relics Shaped the History of Medieval Europe (London - New Haven: Yale University Press, 2011); Cynthia Hahn, Strange Beauty: Issues in the Making and Meaning of Reliquaries, 400-circa 1204 (University Park PA: The Pennsylvania State University Press, 2013); Cynthia Hahn, The Reliquary Effect. Enshrining the Sacred Object (London: Reaktion Books, 2017); Cynthia Hahn and Holger A. Klein, eds., Saints and Sacred Matter. The Cult of Relics in Byzantium and Beyond, Dumbarton Oaks Byzantie Symposia and Colloquia (Dumbarton Oaks: Dumbarton Oaks Research Library and Collection, 2016); Robyn Malo, Relics and Writing in Late Medieval England (Toronto Buffalo - London: Toronto University Press, 2013); Henk van Os, The Way to Heaven. Relic Veneration in the Middle Ages (Baarn: de Prom, 2000); and James Robinson, Lloyd de Beer, and Anna Harnden, eds., Matter of Faith: An Interdisciplinary Study of Relics and Relic Veneration in the Medieval Period, vol. 195, Research publication (London: The British Museum Press, 2015).

6 To the titles listed in the previous footnote can be added a number of important works from the 1980s and 1990s: Arnold Angenendt, Heilige und Reliquien. Die Geschichte ihres Kultes vom frühen Christentum bis zur Gegenwart (Munich: Verlag C. H. Beck, 1994); Édina Bozóky and Anne-Marie Helvétius, eds., Les reliques: Objets, cultes, symboles. Actes du colloque international de l'Université du Littoral-Côte d'Opale (Boulogne-sur-Mer) 4-6 septembre 1997 (Turnhout: Brepols, 1999); Peter Brown, The Cult of the Saints. Its Rise and Function in Latin Christianity, Haskell Lectures on History 
medieval Scandinavia as instruments for the legitimation of royal authority. ${ }^{7}$ The objects in question are passion relics: primarily pieces of the crown of thorns, but also fragments of Christ's cross. The 1523/24 inventory of the treasury of St Mary's Church in Oslo serves as the point of departure, and a number of relics and reliquaries mentioned there will be explored as constituents of a larger pattern of relic use and relic donations associated with royal power in medieval Scandinavia. As vestiges of the most crucial event in the history of salvation, Christ's sacrificial death on the cross on Golgotha, passion relics played an extraordinarily powerful role in the conceptualization of Jerusalem as the pivotal centre of the Christian universe. Their connection to the Holy City was not merely metaphorical, but real: the presence of a passion relic in a Scandinavian church room meant that Jerusalem - in the past, present, and future sense: as the site of the crucifixion, as the earthly destination of pilgrims and crusaders alike, and as the heavenly abode of all blessed after the end of time - became part of the here and now of the faithful. ${ }^{8}$ The fact that a number of thorn relics were in royal possession in Scandinavia in the later Middle Ages adds yet a dimension to the rich weave of symbolic meaning spun around Jerusalem as the centre of medieval Christendom by drawing on the association of this most precious of passion relics to the ideology of the sovereign as a ruler by divine right.

\section{Thorn Relics in Norway and Sweden}

The thorn reliquary given by Philip IV to Haakon V Magnusson in 1304 was not the only one of its kind in Scandinavia. Thirty years earlier, in 1274, a similar gift was exchanged between the fathers of the two monarchs when Philip III of France (1245-1285) presented King Magnus VI Haakonsson (1238-1280, posthumously known as Magnus lagabøte [the Lawmender]) with a thorn relic in a container made from rock

of Religions. New series 2 (Chicago: The University of Chicago Press, 1981); Patrick J. Geary, Furta Sacra. Thefts of Relics in the Central Middle Ages (Princeton NJ: Princeton University Press, 1978); Patrick J. Geary, "Sacred Commodities: The Circulation of Medieval Relics," in The Social Life of Things: Commodities in Cultural Perspective, ed. Arjun Appadurai (Cambridge - New York: Cambridge University Press, 1986); Nicole Herrmann-Mascard, Les reliques des saints. Formation coutumière d'un droit, Société d'histoire du droit, Collection d'histoire institutionelle et sociale 6 (Paris: Éditions Klincksieck, 1975); Anton Legner, Reliquien in Kunst und Kult: Zwischen Antike und Aufklärung (Darmstadt: Wissenschaftliche Buchgesellschaft (WGB), 1995); and Anton Legner, Reliquien. Verehrung und Verklärung. Skizzen und Noten zur Thematik und Katalog zur Ausstellung der Kölner Sammlung Louis Peters im Schnütgen-Museum (Cologne: Schnütgen-Museum der Stadt Köln, 1989).

7 For the role of passion relics in political legitimation in twelfth-century Scandinavia, see Chapter 8 (Lukas Raupp), 140-65.

8 Cf. the introduction to this volume, Chapter 1 (Kristin B. Aavitsland), 18. 
crystal and held by a silver angel. ${ }^{9}$ The gift was collected in France by Archbishop Jon, who brought it to Bergen, up until the early fourteenth century the seat of government of the Norwegian king. At first it was kept in Bergen Cathedral; it was then translated to the Church of the Apostles in Bergen. The transfer concurred with the foundation, by King Magnus in 1275, of a new church to replace the existing structure. The new Church of the Apostles was consecrated in 1302, when Haakon V Magnusson had succeeded to the throne. ${ }^{10}$ An inventory from 1523 of the treasury of the Church of the Apostles confirms that the thorn reliquary was at that time still part of the church's treasury.

Several more instances of possession and exchange of thorn relics in Scandinavian royal circles in the fourteenth century are documented in written sources. In 1304, the same year that Haakon V Magnusson received the thorn relic and the finger relic of St Louis from King Philip IV, the Norwegian king himself presented a thorn from Christ's crown of thorns to the Swedish bishop Brynolf Algotsson of Skara (1248-1317). The gift is described in an office for the celebration of the Feast of the Thorn, September 2, De Spinea Corona. The text does not specify whether the thorn originated from the thorn relic that Haakon V Magnusson had received that same year, or from the relic given to Magnus VI Haakonsson in 1274, or if it had been obtained by other means. ${ }^{11}$ In 1346 , King Magnus Eriksson and Queen Blanca of Norway and Sweden bequeathed a thorn relic in a crystal container studded with gems, together with an unspecified number of other relics deriving from Christ, to the abbey church of the Birgittine monastery in Vadstena. At the time of the donation, the monastery existed only in the mind of the founder, St Birgitta, and in their will the royal couple undertook to realize the plan. ${ }^{12}$

A letter written by King Birger of Sweden (1280-1318) in 1311 offers a remarkable testimony of the solemnity with which royal owners approached their relics. In the missive, the king entrusted the chapter of the Uppsala Cathedral with the task of

9 For King Magnus VI Haakonsson and his mending of Norwegian law, see Chapter 23 (Jørn Øyrehagen Sunde) 500-19.

10 Nicolaysen 1862-1866, Norske fornlevninger: 425-6, 28; Monumenta Historica Norvegiæ. Latinske Kildeskrifter til Norges Historie i Middelalderen, ed. Gustav Storm. Kristiania: A. W. Brøgger, 1880, 73, 146, 194, 332. The reliquary is described in the Breviarium Nidrosienses lectiones for the celebration of the Feast of the Crown of Thorns, November 9 (Islandske Annaler indtil 1578, ed. Gustav Storm. Christiania: Grøndahl \& Søns Bogtrykkeri, 1888, 161-2.)

11 Ann-Marie Nilsson, Sånger till fyra kyrkofester i Skara stift, vol. 62, Skara stifthistoriska sällskaps skriftserie (Skara: Skara stiftshistoriska sällskap, 2011), 83-4; Henrik Schück, "Ur gamla anteckningar X. De spinea corona,” Samlaren. Tidskrift utgifven af Svenska Litteratursällskapets arbetsutskott 39 (1918). On the question of whether Brynolf Algotsson himself is the author of the office, see Toni Schmid, "Smärre liturgiska bidrag VII. Från Capella Regia," Nordisk tidskrift för bok- och biblioteksväsen 20 (1933): 40 and Anders Piltz, "Medeltidskyrkans genrer ca 1150-1520," in Den svenska litteraturen 1. Från forntid till frihetstid 800-1718, ed. Lars Lönnroth and Sven Delblanc (Stockholm: Bonniers, 1987), 71-2.

12 SDHK, 5307. 
safeguarding a number of treasures, among them the royal regalia and a collection of relics, that, due to the king's exacting duties and frequent travelling, were not being treated with proper reverence. The deacons were commanded to place the relics temporarily in the church and to keep a close watch on them. ${ }^{13}$ The letter makes special mention of one of the relics: an angel with a thorn from the crown of thorns [angelum cum spina de corona Domini]. Thus, King Birger owned a thorn reliquary akin to the ones that Magnus VI Haakonsson and Haakon V Magnusson had received from France, and it seems reasonable to ascribe a similar origin to King Birger's relic. Support for this theory is provided by the first lectio in an undated office for May 4, the day of the Feast of the Crown of Thorns. ${ }^{14}$ According to Toni Schmid, the lectio was probably written by one of the clerics of the chapel at the Stockholm royal palace. ${ }^{15}$ It tells how, in 1288, King Philip of France gave "vnam spinam de corona sancta” to King Magnus Birgersson (1240-1290, posthumously known as Magnus Ladulås [Barnlock]), and it is logical to assume that this is the relic that twenty years later was in the possession of King Birger. The office is not an entirely original product: Schmid has noted that the second and third lectio are copied verbatim from the Skara office De Spinea Corona. ${ }^{16}$ The Stockholm office can thus have been written no earlier than 1304, i.e. fifteen years or more after the alleged gift took place. Its part dependence on the Skara office does not necessarily diminish the informative value of the first lectio. Further, whether its assertion of a French royal origin of the thorn relic is historically accurate or not, it shows the importance attached to the very notion of the thorn as a relic deriving from the Holy Crown in Paris. ${ }^{17}$

Reliquaries supported by angels are by no means a feature unique to Scandinavia. In his magisterial Die Reliquiare des christlichen Kultes und ihre Entwicklung (1940), Joseph Braun accounts for a number of relic containers of various kinds - shrines, troughs, ciboria and ostensories - where angels form part of the design; and figure reliquaries shaped as angels are recorded in several registers of objects in precious metal that were confiscated from Swedish churches during the Reformation (cf. below). Nor

13 SDHK, 2435; Hans Hildebrand, "Sveriges medeltid. Kulturhistorisk skildring," vol. 3:5 Kyrkan (Stockholm: P.A. Norstedt \& Söners Förlag, 1898-1903), 641-3.

14 Not to be confused with the Feast of the Thorn that was celebrated in Skara on September 2, the day that King Håkon V Magnusson according to the legend gave the thorn to Bishop Brynolf.

15 Schmid, "Smärre liturgiska bidrag VII. Från Capella Regia,” 38.

16 Schmid, "Smärre liturgiska bidrag VII. Från Capella Regia," 41.

17 In a study of the relics of Skara Cathedral, Harald Widéen constructs a genealogy for the Norwegian and Swedish thorn relics premised on the assumption that the thorn presented to Bishop Brynolf came from one of the two French relic gifts. He further hypothesizes that King Birger's thorn relic was entrusted to Brynolf during his student days in Paris, for him to bring home to King Magnus Birgersson (Harald Widéen, “Skara domkyrkas medeltida reliker," in Skarastudier. Minnesskrift II, Svenska Humanistiska Förbundets Skrifter (Stockholm: Norstedt, 1951), 30). Neither assertion can be verified in historical sources. 
were angels reserved for thorn reliquaries. The museum of San Domenico in Bologna has in its collections a crystal reliquary shaped as a miniature shrine supported by two angels and holding a relic of St Louis given to the church in 1297 by King Philip IV of France: in other words, a gift analogous to the ones received by Magnus VI Haakonsson and Haakon V Magnusson of Norway, but meant to house a relic of the French saintly king instead of a thorn relic. ${ }^{18}$ Additionally, the St-Pierre-St Paul Church in Maubeuge in northern France owns a reliquary held by an angel and containing the veil of the Merovingian saint Aldegunde. ${ }^{19}$ A fifteenth-century reliquary held by three angels and containing a finger bone is today at the Walters Art Museum in Baltimore, whereas the Detroit Institute of Arts owns a fourteenth-century reliquary of French origin, possibly made in Paris, with two angels supporting a rockcrystal container with an unidentified bone. ${ }^{20}$

It is clear, then, that rock-crystal reliquaries supported by angels were in circulation in various contexts in the later Middle Ages. It is nonetheless remarkable that in Scandinavia, between 1274 and 1346, there were three royal examples of thorn relics supported by angels and of alleged French origin. And not surprisingly, these works have attracted the attention of several scholars. Norwegian historians in particular have considered Magnus VI Haakonsson's and Haakon V Magnusson's reception and ownership of the thorn relics in the light of contemporary ideological notions of the nature of royal power, focusing on not only the relics themselves, but also their physical surroundings and the institutional context in which they existed.

\section{The Norwegian Thorn Relics and the Royal Chapels}

Magnus VI Haakonsson's founding of a new Church of the Apostles in Bergen the year after receiving the thorn relic from Philip III has led historians to make comparisons with the choices King Louis IX of France (1214-1270, the future St Louis) made for the most prominent of all thorn relics, namely, the Holy Crown, which the French king bought from Emperor Baldwin II of Constantinople in 1239. To house the acquisition, consisting not only of the Holy Crown but also an additional number of passion relics, Louis IX built Sainte-Chapelle within the precincts of the royal palace on Île de la Cité in Paris. Sainte-Chapelle was consecrated in 1248 and quickly attained status as one of the most celebrated and admired buildings of the Middle Ages. It forms part of a long tradition of oratories and chapels

18 Joseph Braun, Die Reliquiare des christlichen Kultes und ihre Entwicklung (Freiburg im Breisgau: Herder \& Co. Gmbh. Verlagsbuchhandlung, 1940), 177, figs. 03-04.

19 Braun, Die Reliquiare des christlichen Kultes, 314, fig. 17.

20 Walters Art Museum, acc.no. 57.690; Detroit Institute of Arts, acc.no. DIA 28.147. I wish to thank Noëlle Lynn Wenger Streeton for providing me with details about the Detroit reliquary. 
raised in connection to royal palaces for the purpose of housing relics. ${ }^{21}$ It is possible that Magnus VI Haakonsson intentionally attempted to affiliate himself with this tradition when he laid the foundation for the new Church of the Apostles in the royal apple orchard in Bergen. ${ }^{22}$ Although there are no sources explicitly stating so, historians have more or less assumed that the new church was built in large part to provide a fitting setting for the costly relic. ${ }^{23}$ Neither the exact location of the church nor its design are known today, but based on presumed remains of the building, Hans-Emil Lidén and Ellen Marie Magerøy suggest that it may have been a one-aisled structure with a polygonal eastern end, much along the lines of SainteChapelle in Paris. ${ }^{24}$

During this period, St Mary's Church in Oslo was also rebuilt, to enhance its grandeur. The initiative behind the reconstruction has been attributed to Haakon $\mathrm{V}$ Magnusson, and the work may have begun as early as the $1290 \mathrm{~s}$, when he was still a duke. ${ }^{25}$ The fact that King Haakon's will, written in 1312-1319, provided no funds for the work leads Sverre Bagge to conclude that it had been finished by then. ${ }^{26}$ Randi Horgen dates the completion of the building to 1302, based on the burial of King Haakon's father-in-law, Prince Witzlaw, in the church at the turn of the year 1302-1303. ${ }^{27}$ As part of the renovations, the nave, dating back to the 1070s, gained a monumental west-facing section, whereas the eastern part was enlarged with a new transept and a straight-end chancel, all built in brick. ${ }^{28}$

The Church of the Apostles in Bergen and St Mary's Church in Oslo both belonged to a group of royal chapels, fourteen in all, for which King Haakon V

21 Inge Hacker-Sück, "La Sainte-Chapelle de Paris et les chapelles palatines du Moyen Âge en France," Cahiers archéologiques. Fin de l'antiquité et Moyen Âge 13 (1962).

22 Lovgivningen under Kong Magnus Haakonssøns Regjeringstid fra 1263 til 1280, tilligemed et Supplement til første Bind, ed. Rudolf Keyser and Peter Andreas Munch, Norges gamle love indtil 1387 II, Christiania: Chr. Grøndahl, 1848.

23 Reidar Astås, "Kristus-relikvier i norske middelalderkirker," http://www-bib.hive.no/tekster/ Astaas-2011-Kristus-relikvier-i-norske-middelalderkirker.pdf (2011); Sverre Bagge, Den kongelige kapellgestlighet 1150-1319 (Bergen - Oslo - Tromsø: Universitetsforlaget, 1976), 166; Anders Bugge, "Norge," in Nordisk kultur 23. Kirkebygninger og deres udstyr (Oslo: Aschehoug \& Co.s forlag / Stockholm: Albert Bonniers förlag / Copenhagen: J. H. Schultz forlag, 1933), 244; Gerhard Fischer, Norske kongeborger I, Norske minnesmerker (Oslo: J. W. Cappelen forlag, 1951), 231; Hans-Emil Lidén and Ellen Marie Magerøy, Bergen. Norges kirker, vol. I, Norske minnesmerker (Oslo: Riksantikvaren/ Gyldendal Norsk forlag, 1980), 137; Molland, Einar. "Reliker: Norge.” In KLNM, col. 52; Nicolaysen 1862-1866, Norske fornlevninger: 425; Schmid, "Smärre liturgiska bidrag VII. Från Capella Regia,” 36.

24 Lidén and Magerøy, Bergen. Norges kirker, vol. I, 138.

25 Bagge, Den kongelige kapellgestlighet, 174-75; Randi Horgen, "Håkon Vs Mariakirke i Oslo. Bygningsbeskrivelse og tolkninger I, II” (Master Thesis, University of Oslo, 1995), vol. I, 17-20.

26 Bagge, Den kongelige kapellgestlighet, 174.

27 Horgen, "Håkon Vs Mariakirke i Oslo," vol. I, 20.

28 See Horgen, "Håkon Vs Mariakirke i Oslo," for a building description and attempted reconstruction of St. Mary's Church. 
Magnusson acquired a special papal consent, in 1308, allowing him to separate the chapels from the main church organization and treat them as an administrative unit with special privileges. The privileges meant that the clerics were, to a degree, disengaged from episcopal jurisdiction and were instead subordinated to the provost of the Church of the Apostles in Bergen. The provost received the title magister capellarum regis, magister of the royal chapels, and was granted power to propose to the king candidates for the various offices at the chapels, to be ordained by any bishop. The king thus had exclusive right of patronage to the chapels. ${ }^{29}$ Even before the 1308 papal consent, King Haakon had granted extensive privileges to St Mary's Church in Oslo, incorporating the clerics in the secular ranking order of his officials, and promoting the provost to royal chancellor "for all eternity." As a chancellor, the provost safeguarded the royal seal, promulgated royal letters, counted among the king's main advisors, kept accounts of the royal estates and incomes, and acted as a royal envoy. ${ }^{30}$ A first initiative to establish royal chapels with colleges of clerics functioning as royal officials seems to have been taken already by King Haakon IV Haakonsson in the thirteenth century, and was to a certain extent continued by Magnus VI Haakonsson, but it was Haakon V Magnusson who, by attaining the papal privilege in 1308, formalized the system whereby the chapel clergy de facto became royal officials, part of the royal administration. ${ }^{31}$ The appointment of the Oslo provost as magister of the royal chapel formed an essential part of the transfer of the royal government from Bergen to Oslo in the early fourteenth century.

Scholars studying the royal chapels have focused primarily on the clergy as an instrument for the royal exercise of power, both from an executive point of view and as part of the royal power politics vis-à-vis the church and the nobility. ${ }^{32}$ In his study of the royal chapels and their clergy, however, Sverre Bagge points out that the significance of the clergy's religious responsibilities should not be underestimated. A Christian monarch needed clerics who could celebrate Mass, receive confessions and give absolution, and, not least, hold requiems for the salvation of the monarch and the royal family and retinue. ${ }^{33}$ The chapels were potentially important also from a political-ideological point of view, as sites for the propagation of the medieval idea of the divine right of kings. According to high medieval sacropolitical philosophy, the royal office was founded on religious authority: a king received his position by the grace of God, and the continuous liturgical celebration in the royal chapels served as a manifestation of royal sovereignty as a divinely sanctioned institution. In a Norwegian context, the notion of the monarch as rex imago

29 DN, vol. 1, 113; Bagge, Den kongelige kapellgestlighet, espec. 24, 89-95.

30 DN, vol. 1, 143; see Bagge, Den kongelige kapellgestlighet, 89-90, 149-53.

31 Bagge, Den kongelige kapellgestlighet, 59-88.

32 Cf. Bagge, Den kongelige kapellgestlighet, 11-15.

33 Bagge, Den kongelige kapellgestlighet, 158-9. 
Dei and rex iustus - the image of God and God's righteous representative on earth finds its main expression in The King's Mirror [Konungs Skuggsiá], written c.1250 during the reign of Haakon IV Haakonsson. ${ }^{34}$ Here, the king is defined as the anointed of the Lord, ruling by authority bestowed by God directly. His demand for complete submission from the subjects is absolute, but he is also morally obliged to imitate God in wisdom and to rule over his realm as God rules the universe. ${ }^{35}$

This sacro-political ideology is a key factor in Hege Roaldset's study of the religious functions of St Mary's Church in Oslo. She interprets the relics given by Philip IV to Haakon V Magnusson as essential components in the Norwegian king's staging of himself as a divine ruler in the model of the French monarchy, and in particular Louis IX. She draws attention to the fact that a royal chapel founded by Haakon V Magnusson on the island of Tyssøy was dedicated to St. Louis, and she makes a comparison between the king's presentation of a thorn relic to the Skara bishop and the distribution of St Louis relics by French kings to foreign rulers and religious institutions. ${ }^{36}$ Her conclusion is that King Haakon deliberately sought to model himself on Louis IX as a royal ideal. ${ }^{37}$ She further agrees with Arne Odd Johnsen in assuming that King Haakon placed the thorn relic and the St Louis relic in St Mary's Church as part of a strategy to promote Oslo as the new political centre of the realm, thereby favouring the Oslo church over the Church of the Apostles in Bergen with regard to relics. ${ }^{38}$

Considering that the Church of the Apostles already possessed that most precious of relics, a thorn from the crown of thorns, it is questionable whether St Mary's Church gained any advantage in that respect. If it is correct, as is assumed by Johnsen and Roaldset, that Haakon V Magnusson placed the relics in the church, it may be that he was deliberately attempting to emulate Magnus VI Haakonsson's

34 The King's Mirror is also discussed at length in Chapter 23 (Jørn Øyrehagen Sunde), 501-5.

35 "The king represents divine lordship: for he bears God's own name and sits upon the highest judgment seat upon earth [. . . ] it is the duty of everyone upon earth to respect and honor the royal title which an earthly man holds from God [. . . ] For God himself calls the king His anointed, and every king who possesses the full honors of royalty is rightly called the Lord' anointed." The King's Mirror (Speculum regale - Konúngs skuggsjá. (New York-Oxford: The American-Scandinavian Foundation/ London: Humphrey Mildford-Oxford University Press, 1917), 247-8. "[S]ince the king holds his title from God, it is surely his duty to suit his decisions to divine examples." King's Mirror, 290. Cf. Sverre Bagge, The Political Thought of the King's Mirror (Odense: Odense University Press, 1987), 86-112; Sverre Bagge, "Introductory Essay," in Kongespeilet, ed. and trans. Anton Wilhelm Brøgger (Oslo: De norske bokklubbene, 2000), xxi, xliv-liv, and Stefka Georgieva Eriksen, "Popular Culture and Royal Propaganda in Norway and Iceland in the 13th Century," Collegium Medievale. Interdisciplinary Journal of Medieval Research 20 (2007).

36 Cf. Jacques Le Goff, Saint Louis, trans. Gareth Evan Gollrad (Notre Dame IN: University of Notre Dame Press, 2009), 234-8, 702.

37 Hege Roaldset, “Mariakirken i Oslo: de religiøse funksjonene” (Master thesis, University of Oslo, 1996), 72.

38 Johnsen, “Ad Filip IV’s relikviegaver,” 153-164; Roaldset, “Mariakirken i Oslo,” 70, 72. 
deposition of his thorn relic in the Church of the Apostles thirty years earlier. It should be remembered that both churches were key institutions in the establishment of the royal chapels as instruments for the royal administration. This does not diminish the value of Roaldset's contention that the thorn relics symbolically served to confer divine authority to the secular royal power. Being parts of a crown, the thorns by definition carried royal connotations. The lectiones for the Feast of the Holy Crown in Sainte-Chapelle praise the crown as a guaranty of the French monarchy: its glory, it is said, contributes to the elevation of the unshakeable royal throne. ${ }^{39}$ In all instances in Scandinavia where the circumstances of acquisition of a thorn relic are known, a royal person appears as the donor. There are, however, also references to thorn relics without any known royal connection: the relic collection of Lund Cathedral included a fraction of the crown of thorns contained in a small golden crown, and an inventory from 1515 of the relics belonging to Our Lady's Church in Copenhagen lists a monstrance with a thorn relic, in both cases with no indication of how or from whom the relics were obtained. ${ }^{40}$ Nevertheless, the indications of royal patronage with regard to furnishing important ecclesiastic institutions with thorn relics are strong enough to support the idea that the relics could carry a special value as tokens of the sacro-political construction of the monarchy as divinely instituted, and the sovereign as the Lord's anointed representative on earth.

\section{The Silver Statuette and the Relic Board}

The second item in King Philip IV's gift to Haakon V Magnusson, the silver statuette of St Louis containing a finger bone from the saint, can be interpreted as a further contribution to the symbolic construction of royal power as a divine right to rule emanating directly from the will of God, this because St Louis was the paragon of royal sovereignty by divine right. Moreover, he was the crusader king par excellence of the later Middle Ages. He had taken the cross twice, mounting crusades to Muslim territories in North Africa, and from the moment of his death in 1270 on the second crusade in Tunis, moves were taken to confirm his sanctity by canonization. This came through in 1297, making St Louis the last king of the Middle Ages to be canonized..$^{41}$ In the early fourteenth century, the calls to take the cross and recover the Holy Land were as strong as ever, not least in Norway where the

\footnotetext{
39 Claudine Billot, Les saintes chapelles royales et princières (Paris: Éditions du patrimoine, 1998), 12. 40 Göran Axel-Nilsson, Thesaurus Cathedralis Lundensis. Lunds domkyrkas medeltida skattsamling, vol. 30, Acta Regiae Societatis Scientiarum et Litterarum Gothoburgensis, Humaniora (Gothenburg: Kungl. Vetenskaps- och Vitterhetssamhället, 1989), 90 (the thorn relic of Lund Cathedral); SRD vol. VIII, 264; Niels-Knud Liebgott, Hellige mænd og kvinder (Højbjerg: Wormianum, 1982), 124 (the thorn relic of Our Lady's Church, Copenhagen).

41 Gaposchkin, The Making of St Louis.
} 
archbishop of Nidaros was urged repeatedly by the pope in Avignon to contribute to a new crusade by preaching and collecting money from the people. Seen in this light, it is tempting to read the gift's combination of a thorn relic and a relic of St. Louis as a message about the holy duty of a Christian king to support by all means the winning back for Christendom of the kingdom of Jerusalem.

Reliquaries of this nature - a figurine depicting the saint from whom the relic inside supposedly derived - was a common feature of late medieval relic collections. In Scandinavian written sources from the Late Middle Ages and the Reformation, several notations of such reliquaries are found. Ordo in ostensione sanctarum reliquiarum, a ritual from the end of the 1470 s prescribing the order in which to display the contents of the treasury of Lund Cathedral, lists five silver figure reliquaries: St Lawrence (two), St Mary Magdalene, St Sigfrid, and St Knud. ${ }^{42}$ The relic inventory from Our Lady's Church in Copenhagen contains six figure reliquaries. ${ }^{43}$ Swedish confiscation registers from the time of the Reformation document the seizure of a number of figures in precious metal: from St Nicholas Church in Stockholm images of St Barbara, St Henrik of Finland, and St Catherine; from Västerås Cathedral images of St John, St Jerome, St Sebastian, and St Lawrence; from Bälinge Church in Uppland two images in gilded silver showing St Nicholas and the Virgin; from St. Mary's Church in Visby, Gotland, three angels in silver and an image made from pure gold; from the monastery of the Order of St John in Eskilstuna a gilded image of St John; from Stora Kopparberg Church in Dalarna two silver images; from Vika Church in Dalarna one silver image; and from Perno Church in Finland three images representing St Lawrence, St Michael, and St Erik. ${ }^{44}$

The only work of this kind that has survived to the present day in Scandinavia is a silver statuette depicting St Catherine of Alexandria. The figure belongs to the so-called Linköping Treasure, a hoard unearthed in 1676 in a field outside the Swedish town of Linköping. An inscription on the socle informs that the statuette was bequeathed by the prebendary priest Nils Johanson Lenck in Stockholm in 1509, supposedly to Linköping Cathedral. ${ }^{45}$ An annotation from the eighteenth century

42 SRD, vol. VIII, 446-56. See also Axel-Nilsson, Thesaurus Cathedralis Lundensis and Hildebrand "Sveriges medeltid," 614-24. All figure reliquaries but one are recorded as containing relics from several saints. The exception is the statuette of St. Knud, where a wrist bone from the Danish royal saint is the only object held within.

43 SRD, vol. VIII, 260-8; Liebgott, Hellige mænd og kvinder, 118-28.

44 Olle Källström, Medeltida kyrksilver från Sverige och Finland förlorat genom Gustav Vasas konfiskationer (Stockholm: Svenska kyrkans diakonistyrelses bokförlag, 1939); Carl R. af Ugglas, "Prolegomena till ett studium av det kyrkliga guld- och silversmidet i Sverige,” Konsthistorisk tidskrift IV (1935); Horskjær and Norberg, "Relikvarium," 58.

45 Statens Historiska Museum (the Museum of National Antiquities), Stockholm, inv. no. SHM 5. Hildebrand, "Sveriges medeltid. Kulturhistorisk skildring," 639-41; Carl R. af Ugglas, Kyrkligt guldoch silversmide, Ur Statens historiska museums samlingar 2 (Stockholm: Wahlström \& Widstrands Förlag, 1933), 39. 
states that it then contained a bone from St Catherine of Vadstena, in all likelihood a misunderstanding due to a mix-up of saints. ${ }^{46}$ The 1523/24 inventory of the treasures of St Mary's Church in Oslo mentions two gilded saints' images, the St Louis statuette and an image of St Erik. Relics of the Swedish saintly king were on several occasions removed from the shrine in Uppsala Cathedral and sent to churches abroad. ${ }^{47}$ The Oslo statuette may well have contained relics of the saint, although no sources survive to validate that this was in fact the case.

The 1523/24 inventory features yet another relic container with royal connotations: the silver-plated relic board. King Haakon V Magnusson alludes to what in all likelihood is this board when he bequeathed silver for the manufacturing of a similar item for the Church of the Apostles in Bergen. The board in question was probably a panel-shaped reliquary of a format commonly associated with Byzantine staurothekai, reliquaries of the True Cross known to have existed from at least the tenth century onwards. After the Crusader conquest of Constantinople in 1204 and the ensuing influx of Eastern Roman objects into Western Europe, the type became increasingly common in the West. Surviving exemplars, together with numerous references in written sources, testify to its popularity in the later Middle Ages. ${ }^{48}$ A panel reliquary could comprise a single panel, or it could be a diptych or a triptych. The early Byzantine staurothekai were normally made to contain fragments of the True Cross. Cross relics were equally the centre pieces of many Western panel reliquaries, but here often supplemented by additional relics. Unusual for a relic, the wooden fragment of the Holy Cross was often left bare and visible, mounted in a cavity in the centre of the panel. Other relics were instead wrapped up in silk and either placed in glass receptacles or secured behind a metal cover perforated by ornamented openings or windows. Other varieties had the relics mounted behind rock crystals set in the frame of a painting, enamel or relief. A label, or cedula, identifying the saint in question, was attached to each relic.

Providing that King Haakon's instructions about the manufacturing of a panel reliquary for St Mary's Church were followed, at least two such objects have existed in Norway. Interestingly, King Haakon's daughter Ingeborg (1301-1361), spouse of the Swedish duke Erik Magnusson (1282-1318), donated two gold panels to Uppsala Cathedral more or less at the same time as her father drew up his will. Carl R. af Ugglas identified the panels as probable panel reliquaries, and posited that the donation was made in 1318, i.e. the year Ingeborg was recognized as regent during the minority of her son, Magnus Eriksson, after the death, in prison, of Erik Magnusson and the deposition from power of King Birger, the brother of Erik. ${ }^{49}$ Swedish and Danish sources contain a number of references to panel reliquaries in churches,

46 Hildebrand, "Sveriges medeltid," 641.

47 SDHK, 33512; SDHK, 22977.

48 Braun, Die Reliquiare des christlichen Kultes, 262-76.

49 SDHK, 4947; af Ugglas, "Prolegomena," 25. 
several of which were donated by royal personages. In 1377, Queen Margrethe I of Denmark (1353-1412) gave a gilded panel set with relics to the Cistercian monastery in Ås, Halland..$^{50}$ In 1454 , Vadstena Monastery recorded the ownership of a tabula in gold, donated by King Erik of Pomerania (1381-1459) and Queen Philippa. ${ }^{51}$ In 1478, Kristina, daughter of King Karl Knutsson Bonde of Sweden (1408-1470), presented Vadstena Monastery with a golden panel set with relics that her father had bequeathed to the monastery. ${ }^{52}$ In 1503 , the chapter of Strängnäs Cathedral turned over a number of pawned items, among these a panel reliquary, to the Swedish regent Sten Sture (c.1440-1503), who undertook to either cover the loan or return the objects. ${ }^{53}$ In none of these cases is information provided about what relics the panels contained. Considering the noble rank of the donors, it is not unlikely that several may have held a precious cross relic in their centre: fragments of the Holy Cross belonged to the highest rank in the medieval hierarchy of relics, and they feature in at least three more instances of royal donations to Scandinavian churches.

\section{The True Treasures of the Church}

St Mary's Church in Oslo was not alone among the royal chapels to receive relics from King Haakon V Magnusson. The seventy marks pure silver that he bequeathed to the Church of the Apostles in Bergen were intended not only for a panel reliquary but also for the making of two arm reliquaries and "two silver woven cloths set with relics" [duos textus argenteus cum reliquiis in eisdem existentibus]. ${ }^{54}$ Additionally, St Olav's Church on Avaldsnes and St Michael's Church in Tønsberg were given the proprietary right to relics already present in the churches, but theretofore apparently owned by the king. ${ }^{55}$ The donations can be understood in part to be an investment in the churches as components in the newly established system of royal chapels. Seen from a Nordic perspective, however, they also fit into a larger pattern of late medieval royal endowments of costly reliquaries with relics to important

50 SDHK, 11078.

51 Scriptores rerum Svecicarum medii aevi ex schedis praecipue Nordinianis collectos dispositos ac emendatos, ed. Ericus Michael Fant, I, Uppsala, 1818,; Hildebrand, "Sveriges medeltid," 643; af Ugglas, "Prolegomena," 25.

52 SDHK, 30357. I wish to thank Jonas Carlquist, who drew my attention to this diploma.

53 Källström, Medeltida kyrksilver, 261 n. 2.

54 The silver woven cloths set with relics were presumably Reliquientüchlein, textile cloths with relics fastened onto them, of the kind described and illustrated by Joseph Braun in Die Reliquiare des christlichen Kultes, At the time of Braun's writing, one such cloth from the late thirteenth century existed in the Halberstadt Cathedral. Braun, Die Reliquiare des christlichen Kultes und ihre Entwicklung: 508-509, Figs. 95, 96.

55 DN, vol. 4, 128. 
ecclesiastic institutions. To the donations already accounted for can be added a further four from the fourteenth and fifteenth centuries. The thorn reliquary that King Magnus Eriksson and Queen Blanca of Sweden bequeathed to the monastery in Vadstena in 1346 was accompanied by two head reliquaries with relics from the 11,000 virgins, a silver cross with a cross relic and three reliquaries made from gams ægg, probably ostrich eggs. ${ }^{56}$ In 1376, the chapter of Lund Cathedral received a monstrance made from beryl, mounted on a gold base and containing unspecified relics, from Queen Margrethe I of Denmark. ${ }^{57}$ The cathedral's late medieval ritual Ordo in ostensione sanctarum reliquiarum lists a gem-studded golden cross with a cross relic donated by Queen Margrethe, and an ostensory with yet another cross relic offered by Queen Dorothea of Denmark. ${ }^{58}$

A gift of this sort was indeed a regal present, and it was not uncommon for the monetary value of the donated items to be carefully recorded in the sources. The 1304 account of the jewels of King Philip IV of France specify the material value of the two reliquaries sent to the Roi de Noroi as 595 livres and 10 sous. The 1523/24 inventory of the treasures of St Mary's Church in Oslo records the weight of each reliquary in lots, marks and pounds. Haakon V Magnusson's will from 1312-1319 stipulated the value of the silver to be used for the making of the panel reliquary and the two arm reliquaries, whereas no mention is made of their planned content, the relics: it is unclear whether they formed part of the church's existing collection or were to be acquired from elsewhere. Nonetheless, for medieval society the main value of a reliquary lay not in the luxurious materials and exquisite craftsmanship: it was the relic, or relics, inside that constituted the true treasure. This point is made clear in the very first recounting of the veneration of saints' relics among the early Christians, a letter written by the Christian congregation of Smyrna after the martyrdom of their bishop, St. Polycarp, in 155:

We took up his bones, which are more valuable than precious stones and finer than refined gold, and deposited them in a suitable place. There gathering together, as we are able, with joy and gladness, the Lord will permit us to celebrate the birthday of his martyrdom in commemoration of those who have already fought in the contest. ${ }^{59}$

56 SDHK, 5307.

57 SDHK, 10893; SRD, vol. VIII, 454-55; Göran Axel-Nilsson, Storpolitiskt furstebröllop i Lund på drottning Margaretas tid. Gotisk prakt under romanska valv då Erik av Pommern äktade Filippa av England (Lund: Gleerupska Universitetsbokhandelns förlag, 1985), 6-7; Axel-Nilsson, Thesaurus Cathedralis Lundensis, 36, 105; Carl Georg Brunius, Skånes konsthistoria för medeltiden (Lund: C.W.K. Gleerup, 1850), 559.

58 SRD, vol. VIII, 447; Axel-Nilsson, Storpolitiskt furstebröllop i Lund, 12; Axel-Nilsson, Thesaurus Cathedralis Lundensis; Hildebrand, "Sveriges medeltid,” 615.

59 Joseph Barber Lightfoot, J. R. (transl.) Harmer, and Michael W. Holmes, "The Martyrdom of Polycarp," in The Apostolic Fathers (Leicester: Apollos, 1990), 18. 
The splendour of the relic containers was to be seen as a means, not an end in itself. The sumptuousness of the exteriors conveyed both the infinitely higher value of the content within, and the glory of the saints' continued existence in the Heavenly Jerusalem. Just as the saints in the kingdom of heaven were surrounded by jewelled walls and walked through gates of pearls on streets paved with gold ( $\operatorname{Rev} 21: 10-21$ ), their remains on earth were held in containers made from the most precious materials available. The analogy between the gem-studded container and the divine abode extended to the saints themselves: they were the living stones, the lapides vivi (1 Pet 2:5) of the New Jerusalem, making up the very fabric of the civitas dei that would receive the blessed at the end of time. ${ }^{60}$ In this image, the saints and the Heavenly City merged into one radiant body, metaphorically communicated to the beholder by the golden glow of the casket.

In one instance, documents indicate that the royal gift was conditional. In receiving a gilded panel reliquary from Queen Margrethe I of Denmark in 1377, the Cistercians of Ås Monastery were committed to celebrating a daily requiem for the souls of the queen's deceased parents and their relatives in addition to a yearly Mass for the same persons on the anniversary of the death of her father, King Valdemar IV of Denmark. ${ }^{61}$ This observance required of the monastery is in line with practice observed by Sverre Bagge of the celebration of requiems for the royal family and retinue among the main duties of the clergy of the royal chapels in Norway. Yet another of Queen Margrethe's gifts may have carried familial connotations. The title deed to the beryl monstrance presented by the queen to the chapter of Lund Cathedral in 1376 mentions only the queen as donor, but in the ritual Ordo in ostensione sanctarum reliquiarum it is her young son, King Olav Haakonson (1370-1387), who is named as the benefactor. Göran Axel-Nilsson suggests that the bequest was initiated by Queen Margrethe on the occasion of the formal election of the child Olav as king that year. ${ }^{62}$

Actions such as these should be understood as more than expressions of personal piety. For a medieval regent such as Queen Margrethe, the personal was always

60 Legner 1995, Reliquien in Kunst und Kult, 4; Jean-Claude Schmitt, "Les reliques et les images," in Les reliques: Objets, cultes, symboles. Actes du colloque international de l'Université du LittoralCôte d'Opale (Boulogne-sur-Mer) 4-6 septembre 1997, ed. Edina Bozóky and Anne-Marie Helvétius (Turnhout: Brepols, 1999), 152.

61 SDHK, 11078.

62 Axel-Nilsson, Thesaurus Cathedralis Lundensis, 36, 105. According to Axel-Nilsson, the donation took place in conjunction with a celebration of the newly elected king in Lund in 1376. No such celebration is recorded in the written sources, however. Nor has it been possible to validate Axel-Nilsson's assertion that Queen Margrethe I donated the cross reliquary to Lund Cathedral on the occasion of Erik of Pomerania's marriage to Philippa in the Cathedral, October 6, 1406 (Axel-Nilsson, Storpolitiskt furstebröllop i Lund, 12; Axel-Nilsson, Thesaurus Cathedralis Lundensis, 37-8, 89. 
political, even for relics. As noted above, Hege Roaldset concludes that, through the manner in which he chose to keep his relics from the French saintly king, Haakon V Magnusson purposefully imitated Louis IX as a Christian ideal king. ${ }^{63}$ And in a similar manner, Queen Margrethe's donations can be understood as a sacro-political message about her regency as a divinely sanctioned position of authority. In his book Holy Bones and Holy Dust: How Relics Shaped the History of Medieval Europe, Charles Freeman presents numerous examples of how the possession of relics - the more numerous and potent, the better - could translate into political power. The presence of a saint, through his or her relics, conveyed status to the site and to the institution administering it; and these relics served as effective weapons in the struggle for power and authority. Charlemagne distributed relics of Frankish saints across his empire to consolidate his authority, and by the first millennium, saints, in the form of their relics, were taken to regional councils in southern France to help enforce Pax Dei, the Peace and Truce of God, in protection of the church and the common population against the consequences of rampant rivalry and warfare between members of the nobility. ${ }^{64}$ The competition for control over the cult of relics from important saints in Italian city-states in the High and Late Middle Ages offers further proof of the importance of relics in medieval power politics. ${ }^{65}$ If Axel-Nilsson is correct in assuming that Queen Margrethe gifted the chapter of Lund Cathedral with the beryl monstrance on the occasion of the election of Olav as king, the donation can be understood as an effort to secure the backing of the saints, and of the chapter of the cathedral, for the new monarch.

\section{Relic Collections and Relic Feasts}

Judging from surviving records from the cathedrals of Lund and Uppsala and Our Lady's Church in Copenhagen, the royal gifts helped to expand relic collections that could grow to considerable dimensions, although not to the extent seen on the Continent, where the largest collections counted thousands of relics. ${ }^{66} \mathrm{~A}$ list of the relics of Uppsala Cathedral compiled in 1344 enumerates relics from fiftyseven identified saints and an additional number of anonymous saints. ${ }^{67}$ The ritual from Lund Cathedral contains relics from 207 named saints and a host of

63 Roaldset, "Mariakirken i Oslo," 118.

64 Freeman, Holy Bones, Holy Dust, 75, 80-4.

65 Freeman, Holy Bones, Holy Dust, 157-8.

66 Angenendt, Heilige und Reliquien, 158-62; Holger A. Klein, "Sacred Things and Holy Bodies: Collecting Relics from Late Antiquity to the Early Renaissance," in Treasures of Heaven. Saints, Relics and Devotion in Medieval Europe, ed. Martina Bagnoli, et al. (London: The British Museum Press, 2011), 59-64; Legner 1995, Reliquien in Kunst und Kult: 103-116.

67 SDHK, 4953. 
unidentified saints distributed in fifty-seven reliquaries and shrines. The inventory made in 1515 of relics belonging to Our Lady's Church in Copenhagen lists forty-one reliquaries holding over two hundred relics. In contrast, Stavanger Cathedral in 1517 possessed a mere thirty relics, eight of which had been recently acquired in Rome. ${ }^{68}$

Whether their numbers were large or small, relics constituted an essential feature of the sacral environment of the church to which they belonged. The church interior was an arena where heaven and earth merged, and the saints, through their relics, contributed to this melding of the worldly and the divine. The saints existed simultaneously in the Heavenly Jerusalem and in the shrines and reliquaries where their earthly remains rested. The relics mediated the presence of the saints. A relic was still part of the living saint; the bones and knuckles were not just lifeless matter, leftovers from a deceased individual. The relics were the saints, alive and capable to act on behalf of mankind. ${ }^{69}$ This presence, however, was not necessarily allowed to manifest itself visually before the eyes of the faithful. The relics were enclosed in shrines and reliquaries, and even when they were visible in rock-crystal containers, they were wrapped up in protective covers of silk that shielded them from direct view. Furthermore, for most of the year the reliquaries and their contents were safely stored in the treasuries, to be brought out and put on display only on special occasions, such as the important church feasts, when they were solemnly paraded in the processions that constituted an essential feature of any major liturgical celebration. ${ }^{70}$ Thus, according to Axel-Nilsson, most of the relics of Lund Cathedral were kept in the canons' sacristy adjacent to the chancel. ${ }^{71}$ The ritual Ordo in ostensione sanctarum reliquiarum does, however, describe three reliquaries of copper as being placed permanently on the main altar, and ends by stating that "Moreover, in many spaces in the church and in particular on the altars - there are around sixty of them - there are expensive relics from many saints.",72

In the later Middle Ages, the display of the relic collections of large ecclesiastical institutions was frequently formalized into a festum reliquiarum or ostensio reliquiarum, a feast when the cathedral's collection of relics was brought out and

68 DN, vol. 4, 1074.

69 Arnold Angenendt, "Der Kult der Reliquien," in Reliquien. Verehrung und Verklärung. Skizzen und Noten zur Thematik und Katalog zur Ausstellung der Kölner Sammlung Louis Peters im Schnütgen-Museum, ed. Anton Legner (Cologne: Schnütgen-Museum Stadt Köln, 1989); Derek Krueger, "The Religion of Relics in late Antiquity and Byzantium," in Treasures of Heaven. Saints, Relics and Devotion in Medieval Europe, ed. Martina Bagnoli, et al. (London: The British Museum Press, 2011); Legner 1995, Reliquien in Kunst und Kult.

70 Herrmann-Mascard, Les reliques des saints, 168-9.

71 Axel-Nilsson, Thesaurus Cathedralis Lundensis, 17.

72 SRD, vol. VIII, 455. 
shown publicly. ${ }^{73}$ The heading of the ritual from Lund Cathedral, Ordo in ostensione sanctarum reliquiarum - "Order for the display of the holy relics" - leads AxelNilsson to infer that it was written as an instruction for the public presentation of the relics at the relic feast, which in the Lund diocese fell on July $11 .^{74}$ The list from Our Lady's Church in Copenhagen, where the relic feast fell on the first Sunday after the Feast of St Jacob, July 25, likewise has been assumed to state the order in which the church's reliquaries were to be arranged at the feast, or possibly carried in procession during the celebration. ${ }^{75}$ In 1419, Vadstena Monastery received permission from the pope to acquire relics and put them on view, and in 1420 a letter was issued by ten cardinals granting one hundred days of indulgence for anyone attending the relic display in the abbey church on certain dates. ${ }^{76}$

Relic displays can be understood as instruments for the construction of cathedrals and abbey churches as public institutions, sites for interaction between the ecclesiastic institution and the laity. Being a royal chapel, St Mary's Church in Oslo was a different kind of establishment, and no information exists that speaks to the public presentation of the church's relics, or other rituals connected to them. However, it is by no means unthinkable that such activities occurred: in Paris, King Louis IX initiated a public display of the relics of Sainte-Chapelle on Good Friday, with himself in a leading role. A drawing by Matthew Paris in Chronica Majora depicts the king standing on an outdoor tribune, holding the chapel's cross reliquary in his raised hands while exclaiming ecce crucem domini, and beside him, his brother holds the Holy Crown (Fig. 9.2). ${ }^{77}$ Other sovereigns followed suit: by the mid-fourteenth century, emperor Charles IV had instituted the yearly demonstration of the national relics of Bohemia into a ritual that turned an entire section of the capital, Prague, into a sacralized territory. ${ }^{78}$

73 Herrmann-Mascard, Les reliques des saints, 206-16; Hartmut Kühne, Ostensio reliquiarium: Untersuchungen über Enstehung, Ausbreitung, Gestalt, und Funktion der Heiltumsweisungen im römisch-deutschen Regnum (Berlin: W. de Gruyter, 2000); Legner, Reliquien in Kunst und Kult, 88-119.

74 Axel-Nilsson, Thesaurus Cathedralis Lundensis, 84.

75 Thelma Jexlev, "Vor Frue kirkes relikvier. To senmiddelalderlige fortegnelser," in Historiske meddelelser om København. Årbog (Copenhagen: Selskabet for Københavns historie / Københavns kommune, 1976), 29. There are, in fact, two lists from 1515: one itemizes the reliquaries only, whereas the other provides their contents as well. Thelma Jexlev presumes that the two lists were the result of different uses: the shorter list was a guide for the clerics when they arranged the reliquaries for display, and the longer list was read aloud when the reliquaries were put on exhibit, perhaps one by one, so as to better allow members of the audience to pay observance to their preferred saints, say their prayers and make their offerings (Jexlev, "Vor Frue kirkes relikvier," 40).

76 SDHK, 19311; SDHK, 19440.

77 Corpus Christi College, Cambridge, Parker MS 16 fol. 141v. Cf. Legner, Reliquien. Verehrung und Verklärung, 88.

78 Cf. Legner, Reliquien. Verehrung und Verklärung, 88. 


\section{Legitimating the Royal Office}

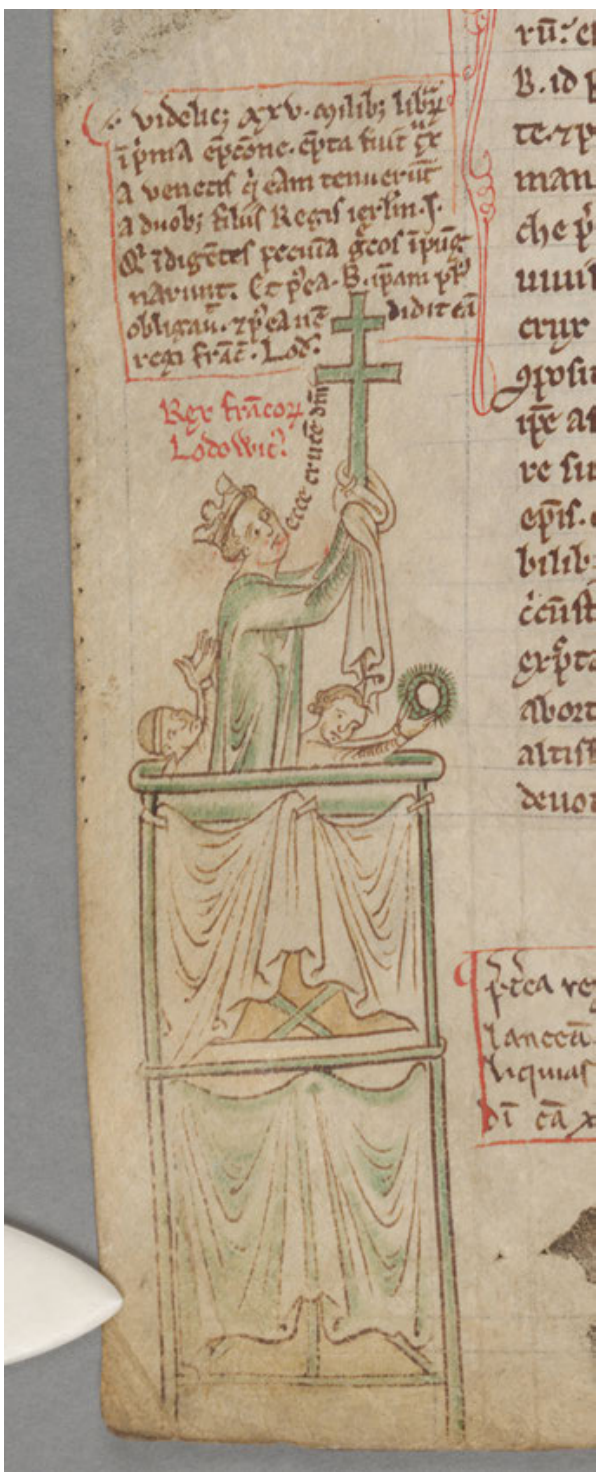

Fig. 9.2: St Louis of France publicly displays the passion relics of Sainte Chapelle on Good Friday. Drawing from Matthew Paris' Chronica Majora, Corpus Christi College, Cambridge, Parker MS 16 fol. 142v.
It remains speculation whether similar ceremonies were staged in St Mary's Church in Oslo: no sources survive that indicate that this was the case. If, indeed, the thorn relic and the other treasures of the chapel were shown in public, the audience need not have been limited to the king and his family and courtiers. As noted by Roaldset, promulgations of indulgences for visitors to St Mary's Church on four different occasions during the fourteenth and fifteenth centuries provide evidence that some degree of accessibility of the church existed beyond what might have been expected considering its status as a royal chapel connected to the palace. ${ }^{79}$ Indulgences are by definition intended to attract visitors to the institution in question. The 1308 papal consent allowing King Haakon $\mathrm{V}$ Magnusson to turn the fourteen churches into royal chapels with special privileges included a general indulgence of 465 days to all penitents who visited any of the churches on its specific feast day or during eight successive days. St Mary's Church received additional privileges in 1386 (forty days indulgence for those who visited or in any way helped the church), 1401 (full indulgence for anyone who visited the church on Mary's Ascension Day, August 15, and gave a donation), and 1439 (forty days indulgence for penitents who

79 Roaldset, "Mariakirken i Oslo," 82-3. 
visited and helped the church on certain days).$^{80}$ Roaldset's survey of letters of donation issued in favour of the church provides further evidence of a wide spectrum of visitors to the church. During the first half of the thirteenth century, the donors belonged exclusively to the royal family, the nobility and the clergy. After the middle of the fourteenth century, however, burghers and farmers began to appear in the documents, and in the first half of the fifteenth century the majority of the benefactors belonged to these two latter categories. ${ }^{81}$

Veneration of the relics of St Mary's Church was not a privilege reserved for the elevated circles of the royal court. The indulgences demonstrate that, at certain times at least, the general public enjoyed entrance to the church. To the extent that the relics were on display in the church - as they most likely were on those days for which indulgences were granted - anyone visiting could turn in prayer to Christ's crown of thorns, St Louis, or any of the other saints - today nameless - whose relics were contained in the panel reliquary and the other reliquaries recorded by Hans Arildson in 1523/24.

From a general point of view, the spiritual benefits offered by St Mary's Church did not differ very much from that of cathedrals and abbey churches with significant relic collections. The distinguishing feature of the church lies in its special status as a royal chapel, augmented by the presence of relics with doubly royal connotations: a piece from the holiest of crowns, a bone from the saintliest of kings, both, moreover, having arrived in the form of gifts from one monarch to another. The thorn relic in particular falls into a pattern of passion relics in royal possession in Scandinavia in the thirteenth, fourteenth and early fifteenth centuries. When the relics were bequeathed to ecclesiastic institutions, complete with sumptuous reliquaries made of gold, silver and rock crystal, they contributed not only to the future salvation of the donor, but also to the promotion of the ideal of royal sovereignty as a divine right, sanctioned by God's will and subject to no authority but God's.

80 DN vol. 1,114; vol. 4, 530; vol 17, 214; and vol. 5, 682.

81 Roaldset, "Mariakirken i Oslo," 83-93. 


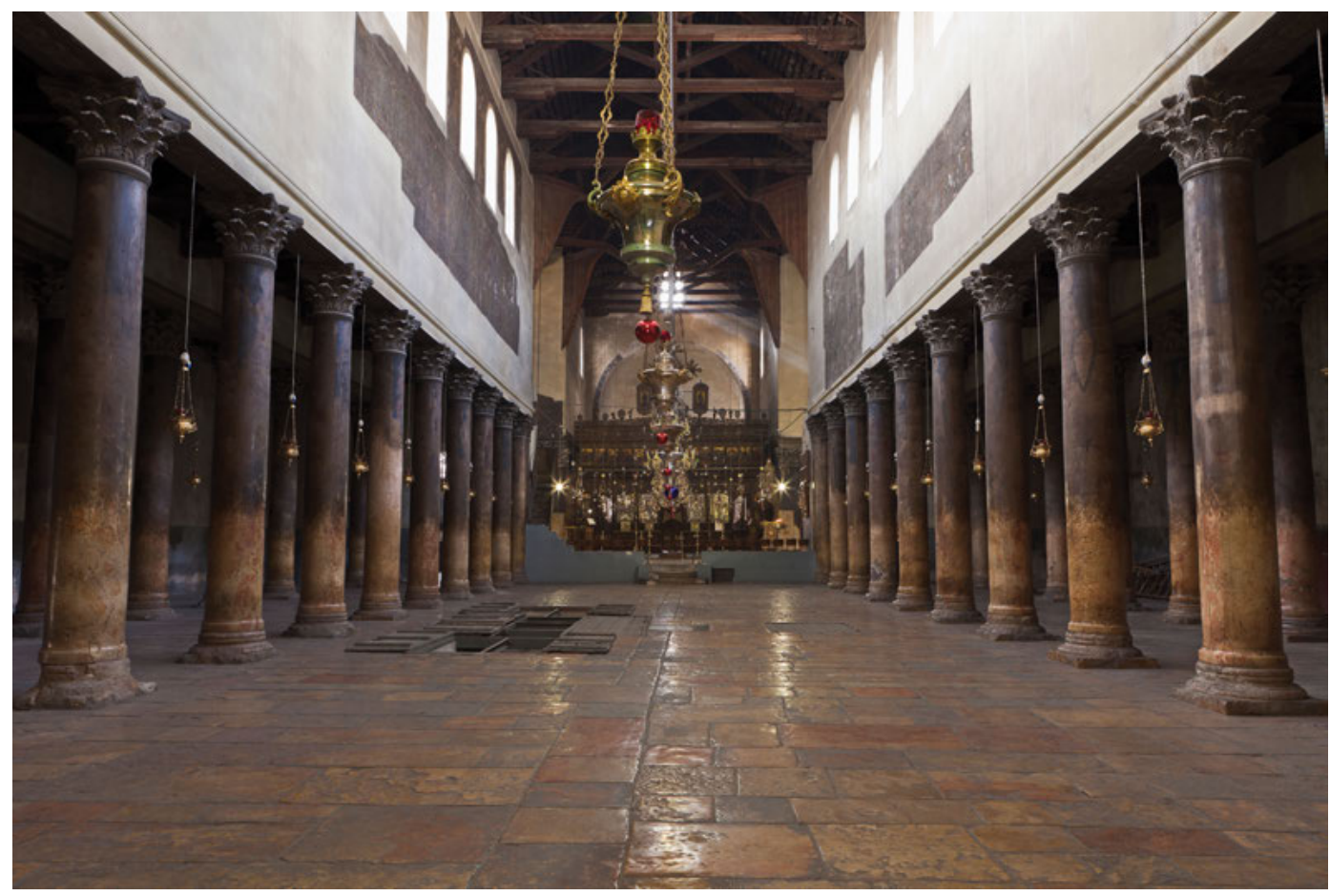

Fig. 10.0: The Church of the Nativity, Bethlehem. The twelfth-century paintings of St Knud and St Olav are on column no. 2 and 3 to the right. 